\title{
The neural crest stem cells: control of neural crest cell fate and plasticity by endothelin-3*
}

\author{
ELISABETH DUPIN, CARLA REAL and NICOLE LeDOUARIN \\ Institut d'Embryologie Cellulaire et Moléculaire (CNRS FRE 2160) \\ 49 bis Avenue de la Belle Gabrielle, 94136 Nogent-sur-Marne, France \\ Manuscript received on July 19, 2001; accepted for publication on July 26, 2001; \\ presented by Vivaldo Moura Neto
}

\begin{abstract}
How the considerable diversity of neural crest (NC)-derived cell types arises in the vertebrate embryo has long been a key question in developmental biology. The pluripotency and plasticity of differentiation of the $\mathrm{NC}$ cell population has been fully documented and it is well-established that environmental cues play an important role in patterning the NC derivatives throughout the body. Over the past decade, in vivo and in vitro cellular approaches have unravelled the differentiation potentialities of single $\mathrm{NC}$ cells and led to the discovery of NC stem cells. Although it is clear that the final fate of individual cells is in agreement with their final position within the embryo, it has to be stressed that the NC cells that reach target sites are pluripotent and further restrictions occur only late in development. It is therefore a heterogenous collection of cells that is submitted to local environmental signals in the various NC-derived structures. Several factors were thus identified which favor the development of subsets of NC-derived cells in vitro. Moreover, the strategy of gene targeting in mouse has led at identifying new molecules able to control one or several aspects of NC cell differentiation in vivo. Endothelin peptides (and endothelin receptors) are among those. The conjunction of recent data obtained in mouse and avian embryos and reviewed here contributes to a better understanding of the action of the endothelin signaling pathway in the emergence and stability of NC-derived cell phenotypes.
\end{abstract}

Key words: neural crest, avian embryo, cell differentiation, endothelin3, peripheral nervous system, melanocytes, Schwann cells, mesectoderm.

\section{INTRODUCTION}

The neural crest (NC) arises at the junction between the prospective epidermis and the prospective neural plate in vertebrates, regardless of whether the NC cells ultimately detach from the open neural folds (as in mammals and amphibians), the closed neural tube (as in birds), or from an ectodermal thickening at the neural plate-epidermis boundary (as in fish). Shortly afterward the morphologically identical NC

\footnotetext{
*Invited paper

Correspondence to: Dr. Elisabeth Dupin

E-mail: dupin@infobiogen.fr / Fax: 33+1 48734377
}

cells migrate extensively throughout the embryo and later give rise to a wide array of derivatives in a variety of sites.

$\mathrm{NC}$ cells contain different subsets of cells that follow distinct migratory pathways and are at the origin of multiple cells in the adult (for references, Le Douarin 1982, Le Douarin and Kalcheim 1999). The levels of the NC along the neural axis have been designated, from rostral to caudal, as cephalic, vagal, trunk, and lumbosacral. The various derivatives of the NC are listed in Table I. The NC was found to give rise to most of the neurons and all the glial 


\section{TABLE I}

Summary of the neural crest-derived cell types in the vertebrate embryo.

\begin{tabular}{l}
\hline N e u r a l c r e s t d e r i v a t i v e s \\
\hline Neuronal cells \\
Sensory ganglia of cranial nerves V, VII, IX, X \\
Spinal ganglia \\
Ganglion cells of the autonomic nervous system \\
Supportive cells of the nervous system \\
Glial cells of the peripheral ganglia \\
Schwann cells of peripheral nerves \\
Meninges of the anterior brain \\
Pigment cells - (except for pigmented retina) \\
Endocrine and paraendocrine cells \\
Adrenomedullary cells \\
Calcitonin-producing cells \\
Type I cells of the carotid body \\
Mesectodermal derivatives - (cephalic neural crest) \\
Visceral and facial skeleton \\
Cranial vault \\
Walls of large arteries derived from the aortic arches \\
Connective tissue of thymus and parathyroid glands \\
Dermis of neck and facial regions \\
\hline
\end{tabular}

cells of the sensory and autonomic ganglia of the peripheral nervous system (PNS), to the entire enteric nervous system, and to various glandular and endocrine cell types. In addition, the cephalic NC from the level of the diencephalon yields mesenchymal cell types forming the so-called mesectoderm, including the facial and head dermis and connective tissue, the smooth muscles of the wall of arterial trunks and most of the skull vault (i.e., parietal and frontal bones) (Couly et al. 1993). In addition, the NC yields the pigment cells (except those of the pigmented retina). Melanocytes are generated along almost the entire axis of the embryo whereas other NC derivatives such as the chromaffin cells of the adrenal medulla and the enteric nerve cells are generated from very restricted regions of the neuroaxis. The NC is therefore regionalized as concerning the different ganglionic neurons (i.e. sensory, autonomic and enteric) belonging to the PNS.

As a population, the NC cells show a great pluripotency when challenged with a new environment by heterotopic grafting (quail-chick neural chimeras). For example, the vagal $\mathrm{NC}$, which normally produces cholinergic gut neurons but no adrenergic cells, produces sympathetic neurons and chromaffin cells when grafted at the trunk level. Similar transpositions of fragments of the neural primordium along the antero-posterior axis have thus revealed that $\mathrm{NC}$ regions have broader developmental capacities than actual fates expressed in the em- 
bryo. Nevertheless, the trunk NC cells are unable to contribute to mesectodermal structures when grafted at cephalic level, therefore suggesting an early developmental restriction of $\mathrm{NC}$ cells caudal to somite 5 as compared to the more rostral cephalic NC.

\section{THE GENERATION OF NEURAL CREST CELLULAR DIVERSITY; THE NEURAL CREST STEM CELL CONCEPT}

A key question in understanding the ontogeny of $\mathrm{NC}$ derivatives is to elucidate how cellular diversity is generated from the apparently homogeneous population of NC cells. Two different scenarios can be made to explain the diversity of cell phenotypes arising from such a pluripotent population of embryonic cells. One possibility is that the NC consists of a heterogeneous assortment of committed unipotent progenitor cells, each programmed to give rise to a particular derivative. These progenitor cells could migrate in a directed fashion to their proper locations and differentiate according to prescribed fates, or they could migrate randomly and those localized in inappropriate sites must either fail to differentiate or die. A second possibility is that the NC is a homogeneous population of multipotent cells, capable of generating any crest derivative under appropriate conditions. Those multipotent cells might migrate randomly and differentiate according to instructive cues encountered along their migratory pathways or at their final sites.

With the establishment of clonal cultures of NC cells and with the complement in vivo single cell tracing experiments, it was revealed that the reality lies somewhere in between these two extremes.

Using a permissive and constant culture medium, that theoretically permitted the differentiation of all NC-derived cell types, it has been possible to study the potentialities of individual cells in vitro. In the 1970s, Cohen and co-workers were first able to establish cultures of trunk NC cells from the quail neural primordium. NC cells in a colony assay generated clones either entirely pigmented, partially pigmented or entirely without pigment obtained (Cohen and Konigsberg 1975). The produc- tion of antibodies to neural antigens later allowed a better characterization of multipotent avian trunk $\mathrm{NC}$ cells, by identifying the existence of both catecholaminergic and sensory neurons in multiphenotypic colonies (Sieber-Blum 1989).

In vitro clonal analysis permitted us to address the controversial question of the origin of mesectodermal lineages from the cephalic NC. Two models could be proposed (Figure 1), a first one assuming an early segregation in the premigratory $\mathrm{NC}$ of mesectodermal precursors from the progenitors of other NC-derived (neural, melanocytic and endocrine) lineages, and a second model where the NC includes highly multipotent cells capable to generate both mesectoderm and other NC derivatives. By seeding migratory $\mathrm{NC}$ cells individually on a feeder layer of growth-inhibited 3T3 fibroblasts and analyzing their progeny with lineage-specific markers, evidence was provided for extremely diverse developmental and proliferative potentialities of NC cells taken from the mes-metencephalic level (Baroffio et al. 1988, 1991, Dupin et al. 1990).

Common progenitors for neurons, adrenergic cells, glia and melanocytes were identified as well as more restricted oligopotent progenitors and committed glial or neuronal precursors. In addition, colonies were obtained that contained both glial and neuronal cells, and cartilage, a main derivative of mesectoderm, a finding which argues against complete segregation of ectomesenchymal and neural progenitors prior to the emigration of $\mathrm{NC}$ cells from the neural primordium. Moreover, the progeny of a single cell included samples of all the major phenotypes represented in the mesencephalic NC derivatives (i.e., glial cells, adrenergic and non-adrenergic neurons, melanocytes and cartilage), therefore implying the existence of a NC stem cell able to yield all derivatives, including mesectoderm (Baroffio et al. 1991). Taken together, these results show that the migrating crest is composed of a heterogenous population of progenitor cells endowed with a variety of developmental capacities. One can hypothesize that these cephalic NC precursors are lineallyrelated (Figure 2), thus supporting the view that, as 


\section{Models for the origin of mesectodermal derivatives from the cephalic neural crest}

\section{TRUNK NC neural cells melanocytes endocrine cells}

CRANIAL NC neural cells melanocytes endocrine cells

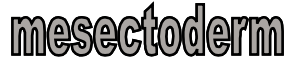

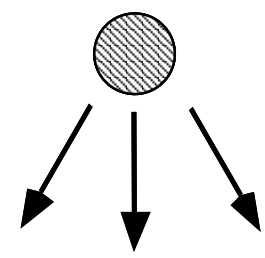

Model 1
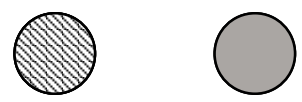

Models

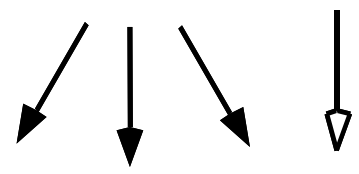

Model 2

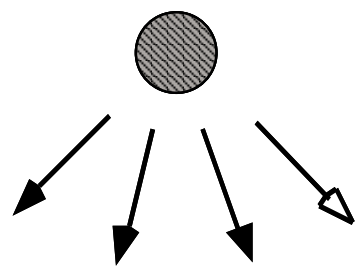

Fig. 1 - Models for the origin of mesectodermal derivatives from the cephalic NC. Cranial and trunk NC share common derivatives (neural cells, melanocytes and endocrine cells) which derive from a multipotent $\mathrm{NC}$ stem cell in the trunk (striped circle). In addition to these trunk-like derivatives, the cephalic NC yields the mesectoderm. Two models can be proposed : Either the mesectoderm is generated from a specific precursor (grey circle) which is segregated early from trunk-like multipotent NC cells (striped circle) (Model 1) ; The other possibility is that common precursors (striped grey circle) are endowed with all cephalic NC potentialities, including the ability to yield mesectodermal derivatives (Model 2).

NC cells divide during migration, progressive restriction takes place in the developmental potentials of the cells generated from an initial pool of multipotent stem cells.

Pluripotency of NC cells was confirmed for mammalian cells by in vitro clonal analysis of mouse (Ito et al. 1993) and rat (Stemple and Ander- son 1992) trunk NC cells. Rat NC cells sorted out by labeling with p75 low affinity NGF receptor and grown in clonal cultures give rise to neurons, glial cells and fibroblasts and these multipotent progenitors self-maintain after serial propagation. Those findings indicate, for the first time, the existence in mammals of NC stem cells defined by the property 


\section{Model for the segregation of cell lineages derived from the cephalic neural crest} (Adapted from Baroffio, Dupin and LeDouarin, 1991)

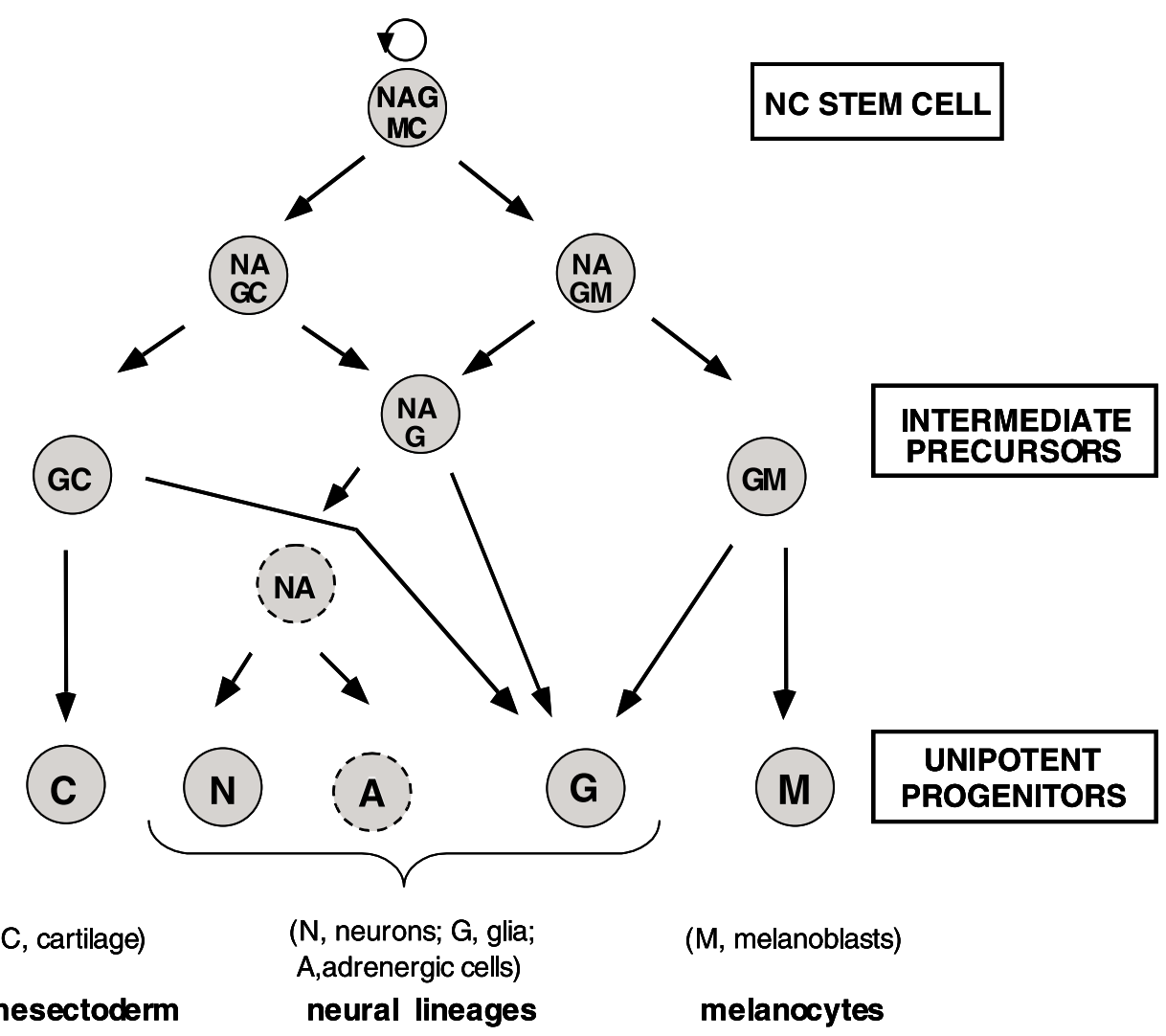

Fig. 2 - Model for the segregation of cell lineages derived from the cephalic NC. Diagram illustrating the different progenitors from quail mesencephalic $\mathrm{NC}$ cells grown in clonal cultures. The presence of cartilage $(\mathrm{C})$, neurons $(\mathrm{N})$, glial cells $(\mathrm{G})$, adrenergic cells $(\mathrm{A})$ and melanocytes $(\mathrm{M})$ was recorded in the colonies. Progenitors have been classified according to the number of these distinct phenotypes in their progeny. The results are consistent with the generation of unipotent progenitors from a 'totipotent' stem cell through several intermediate oligopotent precursors. Filiations between precursors are only hypothetical.

to give rise to multiple phenotypes and to self-renew (Stemple and Anderson 1992).

However, it is possible that crest cells isolated in vitro may behave differently than they do in the living embryo, due to the influence of signals coming from the in vivo environment and from cell-cell interactions. Therefore, an important complement to the in vitro experiments is prospective cell lineage analysis in the intact embryo where an individual cell is labeled in situ so that its descendants can be uniquely identified. By injecting the vital fluorescent dye lysinated fluorescent dextran into individual cells of the chick neural primordium, BronnerFraser and Fraser $(1988,1989)$ have demonstrated the multipotency of NC cells in vivo. The labeled progeny could contain cell types as diverse as sensory neurons, presumptive pigment cells and adrenomedullary cells. However, it was also found 
that NC cells predetermined to the sensory neuron phenotype populate the dorsal root ganglion, thus confirming earlier evidence for the presence of committed sensory neuronal precursors in the premigratory NC (Ziller et al. 1983).

Taken together, these results show that NC cells are heterogeneous in their developmental potentialities, including multipotent stem cell-like progenitors as well as already committed precursors. Therefore, appropriated signals from the environment are required to promote the differentiation of the proper NC-derived cell types in the various derivatives. Knowing the factors that influence the expression of developmental potentialities of NC cells locally and are responsible for final fate decisions is of great importance for understanding the molecular mechanisms underlying NC multipotency.

\section{GROWTH FACTOR CONTROL OF NEURAL CREST CELL FATES}

The evidence for the existence of multipotent progenitors in the $\mathrm{NC}$ raised the question of how these progenitors generate distinct phenotypes in the various NC derivatives. On one hand, cell fate could be assigned by lineage or other cell-autonomous mechanisms. On the other hand, cell fate could be influenced or determined by cell-extrinsic signals. Similar to the model proposed for the hematopoietic system, it seems likely that both types of mechanisms operate in NC cell specification. In this model, multipotent stem cells generate progenitors committed to one or more sublineages, which then proliferate, survive and differentiate in response to specific environmental cues. The process of differentiation necessarily involves many changes in gene expression, which are brought about by regulatory transcription factors acting in the cell nucleus. One goal of studying $\mathrm{NC}$ differentiation is to understand the relationship between the action of environmental signals at the cell surface and the changes in transcriptional regulation that these signals bring about in target cells.

In general, it is thought that NC cells are di- rected toward particular fates by signals localized along migratory pathways and at differentiation sites. Many such factors appear to instruct multipotent NC cells to form specific derivatives. Others appear to act selectively, affecting the proliferation or survival of particular NC progenitors.

Several factors have been identified that direct multipotent rat $\mathrm{NC}$ progenitors to generate specific cell types. The transforming growth factor $\beta$ (TGF $\beta$ ) superfamily is an important group of cytokines that have a role in NC differentiation (Shah et al. 1996). One of the proteins of this group, bone morphogenic protein 2 (BMP2), is involved in the production of sympathetic neurons by trunk NC cells in vivo as well as in vitro. BMP2 is expressed in the dorsal aorta, near which sympathetic ganglia form and it induces the expression by NC cells of $\mathrm{MASH} 1$ encoding a basic-helix-loop-helix transcription factor required for autonomic neurogenesis. In addition, it was suggested recently that local concentrations of BMP2 can determine the choice between sympathetic and parasympathetic fates in rodent NC cells (White et al. 2001). In contrast, TGF $\beta 1$ drives rat NC stem cells to a smooth muscle fate. Both TGF $\beta 1$ and BMP2 act instructively to influence cell fate decisions, rather than selectively to support the survival of lineage-committed progenitors (Shah et al. 1996). Neuregulin1/glial growth factor (GGF), a Schwann cell mitogen of neuronal origin, inhibits neurogenic commitment and promotes glial development of multipotent NC cells in culture (Shah et al. 1994). It is unclear how pluripotent NC cells exposed to multiple signals in vivo integrate them to regulate the outcome of a particular phenotype. However, in vitro experiments of simultaneous and sequential addition of different growth factors to rat $\mathrm{NC}$ cells have revealed that integration of competing influences is influenced by NC stem cell-intrinsic differences in the relative sensitivity and timing of responses to different factors (Shah and Anderson 1997). BMP2 neurogenic signal overrides GGF action at saturating concentrations of both factors; however, GGF can attenuate MASH1 induction by low doses of BMP2, but is not sufficient for 
glial lineage commitment. The generation of glia in PNS ganglia, i.e., in a local environment containing strong instructive neurogenic factors (BMP2), is due to expression by the neuroblasts of Notch ligands, which in turn impairs neighboring cells to enter the neuronal pathway. The loss of neurogenic capacity promoted by activation of Notch signaling is acquired rapidly and irreversibly, leading to glial cell differentiation (Morrison et al. 2000, Wakamatsu et al. 2000).

Another factor that plays a role in NC cell differentiation is retinoic acid (RA), a natural derivative of vitamin A. RA is known to induce in vitro the differentiation of many cell lines of $\mathrm{NC}$ origin (Amos and Lotan 1990) and to cause NC embryopathies after deprivation or administration in excess during vertebrate embryonic development (Morriss-Kay 1993). In vitro experiments have shown that RA favors the development of neuronal lineages derived from the crest (Henion and Weston 1994, Dupin and Le Douarin 1995, Ito and Morita 1995, Rockwood and Maxwell 1996). In cephalic and trunk quail NC clonal cultures, it influences the differentiation of cells when they are in pluripotent state by specifically increasing the number of adrenergic cells in their progeny. RA also stimulates pigment synthesis in melanoblasts differentiating in vitro (Dupin and Le Douarin 1995).

The mouse genetics proved to be very useful for the knowledge of the factors that influence the migration, survival and differentiation of NC melanocytic precursors. Mouse mutants with alterations in coat color have permitted the study of pigment cell development. Two well-known mouse spotting mutants with clear defects in melanogenesis are white dominant-spotting $(w)$ and Steel $(s l)$. Heterozygote mutants have a patchy coat color, whereas homozygotes are either completely white or die during embryogenesis, although the extent of pigmentation deficit varies with different mutant alleles. The analysis of the responsible genes revealed a molecular relationship between the two mutant strains: the $w$ locus encodes the receptor tyrosine kinase c-kit, whereas the $s l$ locus encodes its cognate lig- and, variously known as steel factor (SLF), stem cell factor or mast cell factor (for references, see Reith and Bernstein 1991, Williams et al. 1990, 1992, Galli et al. 1993). A number of in vitro studies of mouse and avian NC suggest that SLF promotes survival and moderate proliferation of melanocytes or their precursors (Murphy et al. 1992, Lahav et al. 1994, Reid et al. 1995). Lahav et al. reported that SLF promotes the appearance of an early marker of melanoblasts/melanocytes in cultured quail NC cells (Lahav et al. 1994).

\section{THE ROLE OF ENDOTHELIN 3 IN NEURAL CREST CELL DIFFERENTIATION}

The endothelins are another determinant group of factors responsible for the differentiation of certain NC derivatives. The endothelins 1, 2 and 3 (EDN1, EDN2 and EDN3) are a family of 21 aa peptides that activate, in mammals, one or both of the two heptahelical, G-protein-coupled endothelin receptors type A and B (EDNRA and EDNRB). EDNRA exhibits different affinities for endothelin peptides and EDNRB accepts all three peptides equally. The EDN1/EDNRA signaling pathway thus acts on cranial NC derivatives. Target disruption of EDNI and EDNRA genes in mouse results in blood pressure elevation and cranio-facial abnormalities. The development of thyroid, tongue and other facial structures is impaired (Kurihara et al. 1994, 1995). Many of these defects are related to abnormal development of NC-derived mesectoderm, which forms most of the connective tissue, cartilage and bones of the head and face. The breakthrough in deciphering the role of EDN3/EDNRB in NC development was the identification of the genetic defects responsible for the Piebald $(s)$ and Lethal spotting $(l s)$ mutations in mouse. These mutations reside in the genes encoding EDNRB (Puffenberger et al. 1994) and its ligand EDN3, respectively (Greenstein-Baynash et al. 1994).

In $l s / l s$ mice, a point mutation in $E D N 3$ impairs the formation of the mature active form of the protein. Moreover, a disruption of the EDN3 gene by homologous recombination leads to an identical $l s / l s$ 
phenotype of coat color spotting and aganglionic terminal gut (megacolon).

Both EDN3 and its receptor EDNRB are therefore necessary for the development of NC-derived melanocytes and posterior enteric nerve cells. In vitro studies have shown that EDN3 favors the development of melanocyte progenitors in mouse and avian NC cultures (Lahav et al. 1996, Reid et al. 1996) (Figure 3). The time at which melanocyte precursors appear probably corresponds to the stage before crest cells need the action of EDNRB/EDN3 receptor-ligand system. In mouse, requirement for functional $E D N R B$ corresponds to a restricted period in melanoblast early migration, before entry into the epidermis (Shin et al. 1999). In avians, human EDN3 peptide is a potent mitogen for NC cells well before the appearance of melanogenic differentiation (Lahav et al. 1996). These observations therefore suggest that in vivo $\mathrm{EDN} 3$ is essential for increasing the early $\mathrm{NC}$ cell population to ensure a sufficient supply of melanoblasts needed for colonizing the entire skin. In addition, the analysis of the effects of EDN3 on single quail NC cells in culture indicates that EDN3 promotes the survival and proliferation of uni- and bipotent melanocyte precursors (Lahav et al. 1998).

In the avian embryo, NC cells initially express $E D N R B$ before they leave the neural primordium, all along the neural axis (Nataf et al. 1996). At later stages, $E D N R B$ is expressed along the mediolateral pathway of NC cell migration in rat embryos (Gariepy et al. 1998). By contrast, EDNRB transcripts are not detected in avian melanocytes and melanoblasts. However, it was found that EDNRB2, a third EDNR identified in birds (Lecoin et al. 1998), is expressed by melanoblasts as soon as they begin to migrate from the migrating staging area near the dorsal neural tube, then when they progress along the medio-lateral pathway and later on during further differentiation of melanocytes. Expression of EDNRB2 in the NC is thus restricted to the cells of the melanocytic lineage which develop in close contact to the epidermal source of the EDN3 ligand (Nataf et al. 1998).
In vitro prolonged exposure to EDN3 causes trunk NC cells to switch from EDNRB to EDNRB2 expression, which eventually results in the positive selection of melanogenic cells (Lahav et al. 1998). In vivo, $E D N R B$, which is expressed by virtually all premigratory and early migratory avian NC cells, is switched off by crest cells which migrate mediolaterally under the ectoderm and which start to express EDNRB2 (Figure 3). It is therefore likely that, during avian skin development, EDN3 synthesized by the epidermis triggers, via activation of EDNRB2, the survival and proliferation of melanoblasts and eventually melanocytes.

\section{PLASTICITY OF NEURAL CREST-DERIVED PHENOTYPES}

Once they have differentiated, functional cells usually maintain their cellular specificity in the multicellular organization of animals. In some pathological conditions, however, such as reparative regeneration, tumorigenesis and carcinogenesis, conversion of cellular specificities can frequently be observed. Lens regeneration observed in the genus Triturus has been considered to be the clearest and most representative example of cell type conversion, as newt lens can be regenerated from the dorsal iris by metaplasia of its pigment cells. The whole neural retina of the newt can also be regenerated from the retinal pigment epithelium. The same results were obtained using the pigment epithelium of chick eyes and, under spreading culture conditions, it was observed the transdifferentiation of chick neural retina into lens and pigment cells (for references, Eguchi and Kodama 1993).

It was demonstrated recently that some of the NC derivatives also show the capacity to dedifferentiate/transdifferentiate in the presence of a growth factor. Clonal cultures of already pigmented melanocytes isolated from the epidermis of quail embryos show high proliferative activity in the presence of EDN3. Such dividing pigment cells progressively loose melanogenic traits and, under prolonged treatment with EDN3, generate a mixed progeny containing not only melanocytes but also cells expressing 

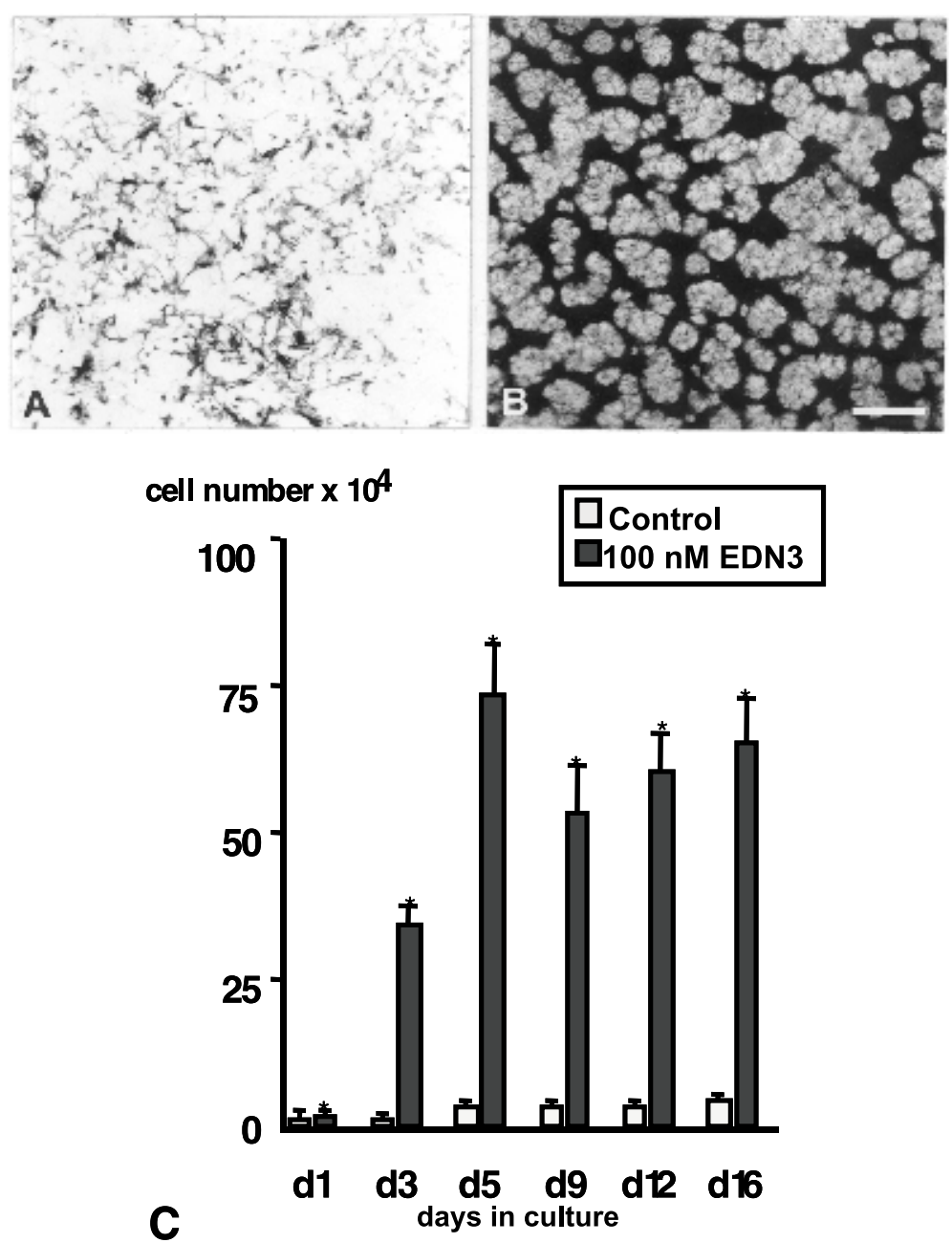

Fig. 3 - Effects of EDN3 on melanogenesis and cell division by quail NC cells in vitro. (A, B) Effect of EDN3 on the pigmentation by trunk NC cells after 11 days in culture. In control medium (A), melanocytes remain dispersed whereas EDN3-treated cultures (B) show reproducible pattern of pigment cells and unpigmented pre-melanocytes. (C) Quantification of EDN3-induced changes of the total cell number at different time points. Cultures of quail trunk NC cells were analyzed during a culture period of 16 days. Significant differences are indicated by a star at the top of columns. (From Lahav et al. 1996).

glial-specific proteins (Dupin et al. 2000). Therefore, epidermal pigment cells in vitro can be reversed to the bipotent stage of glia-melanocytic NC progenitor, which suggests that proliferative signals such as EDN3 may alter the stability of the pigment cell phenotype in vivo.

Similarly, Schwann cells purified from embryonic sciatic nerves and cultured individually respond to EDN3/EDNRB signaling by yielding descendant colonies composed of both glial cells and 
melanocytes. The onset of melanogenesis by dividing Schwann cells occurs progressively, by sequential induction of EDNRB2, early melanocyte antigens and later on melanin synthesis (Dupin, Real, Glavieux, Vaigot and Le Douarin, in preparation).

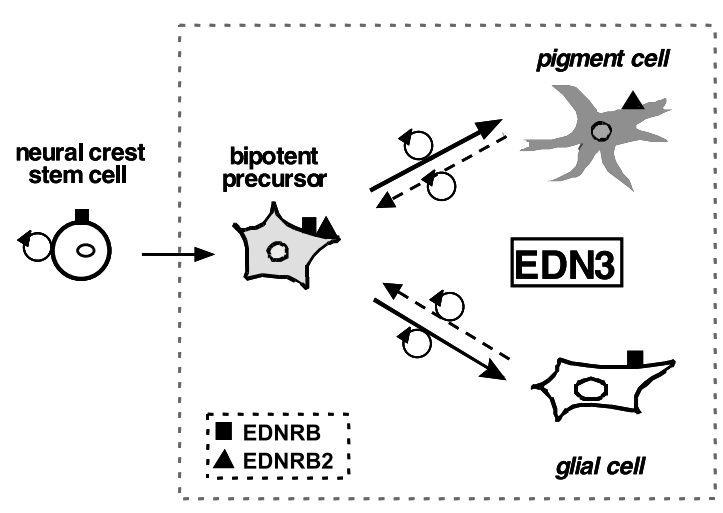

Fig. 4 - Summary of the action of EDN3 on NC precursors and NC-derived cells. EDN3 favor the survival and proliferation of bipotent glial-melanocytic progenitors derived from $\mathrm{NC}$ stem cells in the early NC. Activation by EDN3 of the melanogenic differentiation program involves the induction of EDNRB2 expression by developing melanoblasts, whereas differentiating glial cells continue to express EDNRB. Whether the bipotent cells are able to co-express both types of receptors remains to be ascertained. At later stages, differentiated pigment cells in the epidermis and glial cells in peripheral nerves are able to revert to the immature bipotent stage of their common $\mathrm{NC}$ ancestor under prolonged in vitro exposure to EDN3.

Taken together, these results show that the selection and expansion of melanogenic precursors depend on the local action of EDN3 on bipotent glialmelanocytic NC cells derived from NC stem cells (Figure 4). The immature bipotent stage of this common ancestor can be recapitulated in vitro by differentiated pigment and glial cells, thus providing evidence for the plasticity of NC cell fate which is represented here by the reciprocal conversion between pigment and glial phenotypes. This suggests that EDN3, due to its strong proliferative activity on NC precursors and NC-derived cells, could play a role in vivo in several pathologies implicating both glia and melanocytes, such as neurofibromatosis and tumors of mixed origin.

Abbreviations: EDN3, endothelin 3; EDNRB, endothelin receptor B; NC, neural crest; PNS, peripheral nervous system; SLF, steel factor.

\section{ACKNOWLEDGEMENTS}

We wish to thank Michèle Scaglia for preparing bibliography. This work was supported by the Centre National pour la Recherche Scientifique and Collège de France and by a grant from the Association pour la Recherche contre le Cancer $\left(\mathrm{N}^{\circ}\right.$ 5578). C.R. is recipient of a doctoral fellowship from Fundação para Ciência e Tecnologia, Portugal (SFRH/BD/990/2000).

\section{RESUMO}

O modo como a diversidade dos tipos celulares derivados da crista neural $(\mathrm{CN})$ surge, no embrião de vertebrado, tem sido uma pergunta chave na biologia do desenvolvimento.

A pluripotência e a plasticidade na diferenciação da população de células da $\mathrm{CN}$ têm sido intensivamente documentadas, ficando deste modo estabelecido que os factores ambientais têm um papel importante na correta diferenciação dos derivados da $\mathrm{CN}$ no organismo. Na década passada, estudos in vivo e in vitro, revelaram as potencialidades de diferenciação de células de $\mathrm{CN}$ individuais levando à descoberta de células "stem" (células tronco) da CN. Embora seja claro que a diferenciação celular final das células individuais está de acordo com a sua localização final no embrião, é necessário realçar que as células da $\mathrm{CN}$ que atingem locais alvo são pluripotentes e as restrições impostas nas suas potencialidades ocorrem somente numa fase mais tardia do desenvolvimento. A CN é, deste modo, um conjunto heterogêneo de células que é submetida a sinais ambientais localizados nas várias estruturas derivadas da $\mathrm{CN}$. Foram assim identificados vários factores que favorecem a diferenciação de subgrupos de células derivadas da $\mathrm{CN}$, in vitro. Para além destes factores foram também identificadas novas moléculas capazes de controlar um ou vários aspectos da diferenciação celular da $\mathrm{CN}$ in vivo, através da estratégia molecular de "gene targeting" em ratinho. As endotelinas (e os seus receptores) são um exemplo destas 
moléculas. O conjunto dos resultados obtidos recentemente em embriões de ratinho e de galinha e descritos no presente artigo, contribuíram para uma melhor compreensão do modo de ação da via de sinalização das endotelinas no controlo do aparecimento e da estabilidade dos fenotipos celulares derivados da $\mathrm{CN}$.

Palavras-chave: crista neural, embrião de ave, diferenciação celular, endotelina3, sistema nervoso periférico, melanocitos, células de Schwann, mesectoderme.

\section{REFERENCES}

Amos B And Lotan R. 1990. Retinoid-sensitive cells and cell lines. Methods Enzymol 190: 217-225.

Baroffio A, Dupin E and Le Douarin NM. 1988. Clone-forming ability and differentiation potential of migratory neural crest cells. Proc Natl Acad Sci USA 85: 5325-5329.

Baroffio A, Dupin E and Le Douarin NM. 1991. Common precursors for neural and mesectodermal derivatives in the cephalic neural crest. Development 112: 301-305.

Bronner-Fraser M and Fraser SE. 1988. Cell lineage analysis reveals multipotency of some avian neural crest cells. Nature 335: 161-164.

Bronner-Fraser M and Fraser SE. 1989. Developmental potential of avian trunk neural crest cells in situ. Neuron 3: 755-766.

Cohen AM And Konigsberg IR. 1975. A clonal approach to the problem of neural crest determination. Dev Biol 46: 262-280.

Couly GF, Coltey PM and Le Douarin NM. 1993. The triple origin of skull in higher vertebrates: a study in quail-chick chimeras. Development 117: 409-429.

Dupin E AND Le Douarin NM. 1995. Retinoic acid promotes the differentiation of adrenergic cells and melanocytes in quail neural crest cultures. Dev Biol 168: 529-548.

Dupin E, Baroffio A, Dulac C, Cameron-Curry P AND Le Douarin NM. 1990. Schwann-cell differentiation in clonal cultures of the neural crest, as evidenced by the anti-Schwann cell myelin protein monoclonal antibody. Proc Natl Acad Sci USA 87: 1119-1123.
Dupin E, Glavieux C, Vaigot P and Le Douarin NM. 2000. Endothelin 3 induces the reversion of melanocytes to glia through a neural crest-derived glial-melanscytic progenitor. Proc Natl Acad Sci USA 97: 7882-7887.

Eguchi G and Kodama R. 1993. Transdifferentiation. Curr Opin Cell Biol 5: 1023-1028.

Galli SJ, Zsebo KM and Geissler EN. 1993. The kit ligand, Stem Cell Factor. Adv Immunol 55: 1-96.

Gariepy CE, Williams SC, Richardson JA, Hammer RE AND Yanagisawa M. 1998. Transgenic expression of the endothelin-B receptor prevents congenital intestinal aganglionosis in a rat model of Hirschsprung disease. J Clin Invest 102: 1092-1101.

Greenstein-Baynash A, Hosoda K, Giaid A, RichaRdson JA, Emoto N, HAMmer RE AND YANAGISAWA M. 1994. Interaction of endothelin-3 with endothelin-B receptor is essential for development of epidermal melanocytes and enteric neurons. Cell 79: 1277-1285.

Henion PD and Weston JA. 1994. Retinoic acid selectively promotes the survival and proliferation of neurogenic precursors in cultured neural crest cell populations. Dev Biol 161: 243-250.

ITO K AND Morita T. 1995. Role of retinoic acid in mouse neural crest cell development in vitro. Dev Dyn 204: 211-218.

Ito K, Morita T And Sieber-Blum M. 1993. In vitro Clonal Analysis of Mouse Neural Crest Development. Dev Biol 157: 517-525.

Kurihara Y, Kurihara H, Suzuki H, Kodama T, MaEmura K, Nagai R, Oda H, Kuwaki T, CaO WH, KAMADA N ET AL. 1994. Elevated blood pressure and craniofacial abnormalities in mice deficient in endothelin-1. Nature 368: 703-710.

Kurihara Y, Kurihara H, Oda H, Maemura K, Nagai R, IshiKawa T AND YazaKi Y. 1995. Aortic arch malformations and ventricular septal defect in mice deficient in endothelin-1. J Clin Invest 96: 293-300.

Lahav R, Lecoin L, Ziller C, Nataf V, Carnahan JF, Martin FH and Le Douarin NM. 1994. Effect of the Steel gene product on melanogenesis in avian neural crest cell cultures. Differentiation 58: 133 139.

Lahav R, Ziller C, Dupin E and Le Douarin NM. 
1996. Endothelin 3 promotes neural crest cell proliferation and mediates a vast increase in melanocyte number in culture. Proc Natl Acad Sci USA 93: 3892-3897.

Lahav R, Dupin E, Lecoin L, Glavieux C, Champeval D, Ziller C ANd Le Douarin NM. 1998. Endothelin 3 selectively promotes survival and proliferation of neural crest-derived glial and melanocytic precursors in vitro. Proc Natl Acad Sci USA 95: 1421414219.

Lecoin L, Sakurai T, Ngo MT, Abe Y, Yanagisawa M AND LE DouARIN NM. 1998. Cloning and characterization of a novel endothelin receptor subtype in the avian class. Proc Natl Acad Sci USA 95: 3024-3029.

Le Douarin N. 1982. The neural crest. Cambridge: Cambridge University Press. 259p.

Le Douarin NM and Kalcheim C. 1999. The Neural Crest (second edition). New York: Cambridge University Press. 445p.

Morriss-KAY G. 1993. Retinoic acid and craniofacial development molecules and morphogenesis. Bioessays 15: 9-15.

Morrison SJ, Perez SE, Qiao Z, Verdi JM, Hicks C, Weinmaster G And Anderson DJ. 2000. Transient Notch activation initiates an irreversible switch from neurogenesis to gliogenesis by neural crest stem cells. Cell 101: 499-510.

Murphy M, Reid K, Williams DE, Lyman SD AND BARTLETT PF. 1992. Steel factor is required for maintenance, but not differentiation, of melanocyte precursors in the neural crest. Dev Biol 153: 396-401.

Nataf V, Lecoin L, Eichmann A and Le Douarin NM. 1996. Endothelin-B receptor is expressed by neural crest cells in the avian embryo. Proc Natl Acad Sci USA 93: 9645-9650.

Nataf V, Amemiya A, Yanagisawa M And Le Douarin NM. 1998. The expression pattern of endothelin 3 in the avian embryo. Mech Dev 73: 217-220.

Puffenberger EG, Hosoda K, Washington SS, NaKao K, Dewit D, Yanagisawa $M$ AND Chakravarti A. 1994. A missense mutation of the endothelin-B receptor gene in multigenic Hirschsprung's disease. Cell 79: 1257-1266.

Reid K, Nishikawa Si, Bartlett PF and Murphy M. 1995. Steel factor directs melanocyte development in vitro through selective regulation of the number of c-kit(+) progenitors. Dev Biol 169: 568-579.

Reid K, Turnley AM, Maxwell GD, Kurihara Y, Kurihara H, Bartlett PF and Murphy M. 1996. Multiple roles for endothelin in melanocyte development: regulation of progenitor number and stimulation of differentiation. Development 122: 39113919.

Reith AD And Bernstein A. 1991. Molecular biology of the $W$ and Stell loci. In: Genome analysis. Vol. 3. Genes and Phenotypes. New York: Cold Spring Harbor Laboratory Press, p. 105-133.

Rockwood JM And Maxwell GD. 1996. An analysis of the effects of retinoic acid and other retinoids on the development of adrenergic cells from the avian neural crest. Exp Cell Res 223: 250-258.

SHAH NM AND ANDERSON DJ. 1997. Integration of multiple instructive cues by neural crest stem cells reveals cell-intrinsic biases in relative growth factor responsiveness. Proc Natl Acad Sci USA 94: 11369-11374.

Shah NM, Marchionni MA, Isaacs I, Stroobant P AND ANDERSON DJ. 1994. Glial growth factor restricts mammalian neural crest stem cells to a glial fate. Cell 77: 349-360.

Shah NM, Groves AK and Anderson DJ. 1996. Alternative neural crest cell fates are instructively promoted by TGF beta superfamily members. Cell 85 : 331-343.

Shin MK, Levorse JM, Ingram RS and Tilghman SM. 1999. The temporal requirement for endothelin receptor-B signalling during neural crest development. Nature 402: 496-501.

Sieber-Blum M. 1989. Commitment of neural crest cells to the sensory neuron lineage. Science 243: 16081611.

Stemple DL AND ANDERSON DJ. 1992. Isolation of a stem cell for neurons and glia from the mammalian neural crest. Cell 71: 973-985.

Wakamatsu Y, Maynard TM AND Weston JA. 2000. Fate determination of neural crest cells by NOTCHmediated lateral inhibition and asymmetrical cell division during gangliogenesis. Development 127: 2811-2821.

White PM, Morrison SJ, Orimoto K, Kubu CJ, Verdi JM AND ANDERSON DJ. 2001. Neural crest stem cells 
undergo cell-intrinsic developmental changes in sensitivity to instructive differentiation signals. Neuron 29: 57-71.

Williams DE, Eisenman J, Baird A, Rauch C, VAN Ness K, March CJ, PARK LS, Martin U, Mochizuki DY, Boswell HS, Burgess GS, Cosman D AND Lyman SD. 1990. Identification of a ligand for the c-kit proto-oncogene. Cell 63: 167-174.
Williams DE, De Vries P, Namen AE, Widmer MB And Lyman SD. 1992. The Steel factor. Dev Biol 151: 368-376.

Ziller C, Dupin E, Brazeau P, Paulin D and Le DOUARIN NM. 1983. Early segregation of a neuronal precursor cell line in the neural crest as revealed by culture in a chemically defined medium. Cell 32: 627-638. 